\title{
Hubungan antara Kecemasan dan Kesepian dengan Insomnia pada Lansia
}

\author{
DESI PUSPITA SARI \& HAMIDAH* \\ Fakultas Psikologi Universitas Airlangga
}

\begin{abstract}
ABSTRAK
Insomnia merupakan masalah umum yang dialami lansia karena penurunan pola tidur sebagai akibat dari proses penuaan yang normal. Namun masalah tidur yang diabaikan dapat berdampak pada penurunan kualitas hidup dan kejadian bunuh diri. Perlu evaluasi terkait gejala insomnia yang dapat terjadi sebagai gangguan primer atau akibat dari kondisi komorbid lainnya. Penelitian ini bertujuan untuk mengetahui hubungan antara kecemasan dan kesepian dengan insomnia pada lansia di Surabaya. Penelitian kuantitatif ini menggunakan metode survei dengan melibatkan 94 lansia. Penelitian ini menggunakan alat ukur Insomnia Severity Index, Geriatric Anxiety Scale, dan UCLA Loneliness Scale version 3. Hasil penelitian menunjukkan bahwa kecemasan dan kesepian memiliki hubungan yang positif dan signifikan dengan insomnia pada lansia di Surabaya. Penelitian ini menyimpulkan bahwa lansia yang mengalami kecemasan dan kesepian maka cenderung mengalami insomnia juga.
\end{abstract}

Kata kunci: insomnia, kecemasan, kesepian, lansia di Surabaya

\begin{abstract}
Insomnia is a common problem experienced by the elderly due to decreased sleep patterns as a result of the normal aging process. However, neglected sleep problems can lead to decreased quality of life and the incidence of suicide. Evaluation needed for insomnia-related symptoms that may occur as a primary disorder or as a result of other comorbid conditions. This study aims to determine the correlation between anxiety and loneliness with insomnia in the elderly in Surabaya. This quantitative study used a survey method involving 94 elderly people. This study used a measuring instrument of the Insomnia Severity Index, Geriatric Anxiety Scale, and UCLA Loneliness Scale version 3. The results showed that anxiety and loneliness have a positive and significant correlation with insomnia in elderly in Surabaya. This study concluded that the elderly who has anxiety and loneliness tend to have insomnia too.
\end{abstract}

Keywords: anxiety, elderly in Surabaya, insomnia, loneliness

Buletin Penelitian Psikologi dan Kesehatan Mental (BRPKM), 2021, Vol. 1(1), 595-606

*Alamat korespondensi: Fakultas Psikologi Universitas Airlangga, Kampus B Universitas Airlangga Jalan

Airlangga 4-6 Surabaya 60286. Surel: hamidah@psikologi.unair.ac.id

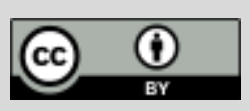

Naskah ini merupakan naskah dengan akses terbuka dibawah ketentuan the Creative Common Attribution License (CC-BY-4.0) (http://creativecommons.org/licenses/by/4.0), sehingga penggunaan, distribusi, reproduksi dalam media apapun atas artikel ini tidak dibatasi, selama sumber aslinya disitir dengan baik. 


\section{PEN D A H U L U A N}

Lansia (lanjut usia) merupakan individu yang mencapai usia 60 tahun ke atas dan berada pada tahap akhir siklus kehidupan. Lansia mengalami proses penuaan yang melibatkan perubahan kumulatif pada tubuhnya, dimana jaringan dan sel-sel tubuhnya mengalami penurunan kapasitas fungsional. Lansia juga rentan terhadap berbagai penyakit atau sindroma karena kemampuan regeneratif tubuhnya yang terbatas dibanding kelompok usia lainnya (Kholifah, 2016). Jumlah penduduk lansia yang semakin tinggi akan meningkatkan angka kebutuhan dalam berbagai aspek kehidupan lansia, baik bagi lansia itu sendiri maupun bagi keluarga nya.

Menurut laporan data Demografi Penduduk International (Bureau of The Cencus USA) tahun 1993 bahwa jumlah penduduk lansia di Indonesia akan mengalami kenaikan sebesar $414 \%$ pada periode 1990-2025 yang merupakan presentase kenaikan tertinggi di dunia. Menurut Badan Pusat Statistik Indonesia tahun 2018, salah satu provinsi yang memiliki jumlah populasi lansia tertinggi di Indonesia adalah provinsi Jawa Timur dengan presentase 12,54\% dari total populasi di Indonesia. Berkaitan dengan hal tersebut, kota yang memiliki penduduk lansia terbanyak di Jawa Timur adalah Kota Surabaya dengan prevalensi 7,9\% dari total populasi lansia di Jawa Timur (BPS Jatim, 2016 dalam Vibriyanti, 2018).

Prevalensi penduduk lansia di Surabaya yang berusia 60 tahun ke atas mengalami kenaikan sebanyak 4\% dalam lima tahun terakhir. Jumlah penduduk lansia di Surabaya pada tahun 2016 sebanyak 227.527 jiwa, tahun 2017 sebanyak 236.541 jiwa, tahun 2018 sebanyak 246.069 jiwa, tahun 2019 sebanyak 256.007 jiwa, dan tahun 2020 sebanyak 266.055 jiwa (BPS, 2020). Berkaitan dengan peningkatan data demografi tersebut maka kesehatan lansia di Surabaya menjadi perlu untuk diperhatikan. Pemerintah Kota Surabaya mengeluarkan Peraturan Walikota Surabaya nomor 3 tahun 2009 dan membentuk posyandu lansia sebagai bentuk perhatian kepada penduduk yang telah lanjut usianya.

Lansia yang tinggal di rumah dianggap lebih sejahtera karena mendapat dukungan dan perhatian dari keluarga, dilibatkan dalam kegiatan sehari-hari dan dapat bersosialisasi dengan masyarakat sekitar seperti mengikuti kegiatan posyandu lansia. Selain itu lansia yang tinggal di rumah bersama keluarganya dianggap dapat lebih membahagiakan karena mereka berada ditengah keluarganya. Namun lansia di Surabaya juga masih mengalami masalah terkait kesehatan fisik maupun psikologis. Permasalahan yang terjadi pada lansia di Surabaya yang tinggal di rumah salah satunya adalah insomnia. Sebuah penelitian mengenai derajat insomnia pada lansia di Posyandu Lanjut Usia Mekar Sari Mojo Surabaya. Penelitian tersebut menunjukkan bahwa sebanyak 67,4\% dari 43 responden mengalami insomnia (Yola, 2016).

Insomnia merupakan gangguan tidur yang paling umum pada populasi lansia (C. Morin \& Benca, 2012). Insomnia didefinisikan sebagai kesulitan memulai dan/atau mempertahankan tidur secara terusmenerus (Savard dkk., 2003). Insomnia ditandai oleh adanya tingkat keparahan gangguan tidur (severity), frekuensi kesulitan tidur (frequency), durasi kesulitan tidur (duration) dan adanya konsekuensi atau dampak di siang hari (associated daytime consequences) (Savard dkk., 2003). Individu dengan insomnia menunjukkan gejala yang paling menonjol diantaranya adalah pemeliharaan tidur yakni sekitar 50\% hingga 70\%, diikuti dengan kesulitan dalam memulai tidur yakni 35\% hingga 60\%, dan tidur tidak restoratif sekitar 20\% hingga 25\% (Buysse \& Merrigan, 2013).

Prevalensi insomnia lebih tinggi pada populasi individu yang lebih tua daripada populasi individu yang lebih muda dengan prevalensi keseluruhan gejala insomnia berkisar dari 30\% hingga 48\% pada lansia, dan sebanyak 50\% lansia mengeluh kesulitan memulai atau mempertahankan tidur (Crowley, 2011). Hasil studi pendahuluan juga menunjukkan bahwa beberapa lansia tepatnya di wilayah Manukan Kulon 
Surabaya mengeluhkan masalah tidur karena berbagai hal yang dialami, diantaranya penurunan kemampuan komunikasi yang membuat mereka merasa tersisih, masalah kesepian yang muncul pasca kematian pasangan, kesakitan dan ketakutan mengenai penyakit, kurangnya waktu interaksi dengan keluarga serta kebutuhan yang besar dalam menjalin hubungan dekat dengan keluarga dan tetangga (Jannati, 2019).

Penelitian lain juga menunjukkan bahwa para lansia cenderung tidur dalam rentang waktu yang lebih pendek dan tidur menjadi kurang nyenyak seiring bertambahnya usia. Perubahan pola tidur berubah sepanjang hidup, merupakan bagian dari proses penuaan yang normal dan dapat disebabkan oleh masalah kesehatan lain, kebiasaan gaya hidup, atau efek samping obat-obatan. Namun masalah tidur pada lansia bukanlah bagian normal dari penuaan (Rajput \& Bromley, 1999). Oleh karena itu evaluasi terkait gejala insomnia menjadi tantangan tersendiri karena gejalanya dapat terjadi sebagai gangguan primer atau akibat dari kondisi komorbid lainnya (Patel dkk., 2018).

Berdasarkan hasil wawancara pada beberapa lansia di Surabaya yang tinggal di rumah, keluhan sulit tidur yang mereka alami dikarenakan usianya yang memang sudah tua sehingga keluhan sulit tidur wajar dialami oleh lansia. Namun gangguan tidur yang tidak segera ditangani akan membawa dampak buruk seperti mengantuk berlebihan di siang hari, gangguan atensi dan memori, gangguan mood, depresi, penggunaan hipnotik yang tidak semestinya, serta penurunan kualitas hidup (Sumirta \& Laraswati, 2014). Selain itu lansia juga mengungkapkan bahwa mereka memiliki kekhawatiran terkait berbagai penyakit medis yang dialami dan ketidakpastian terkait keberlangsungan hidup mereka di esok hari. Kekhawatiran atau kecemasan ini juga muncul pada waktu malam hari sehingga mereka kesulitan untuk tidur dengan tenang dan nyenyak. Sejalan dengan hal tersebut, hasil survei yang dilakukan oleh National Sleep Foundation menunjukkan bahwa insomnia juga lebih sering terjadi pada berbagai gangguan mental lainnya seperti kecemasan (Adler dkk., 2004 dalam Ancoli-Israel \& Cooke, 2005).

Kecemasan juga dialami oleh beberapa lansia di Surabaya. Hal ini didukung oleh penelitian mengenai kecemasan di Posyandu Lansia Mekar Sari Mojo Surabaya. Hasil penelitiannya menunjukkan bahwa sebanyak 41,9\% dari 43 responden mengalami kecemasan (Yola, 2016). Kecemasan merupakan respon terhadap berbagai macam tekanan yang mengakibatkan perasaan takut dan terancam (Segal dkk., 2010). Kecemasan tersebut ditandai dengan adanya gejala somatic (melibatkan respon fisiologis), cognitive (melibatkan respon subjektif dalam pikiran), dan affective (melibatkan perasaan individu). Kecemasan pada lansia dapat disebabkan oleh penyakit medis fisiologi yang sulit diatasi, kehilangan pasangan hidup, pekerjaan, keluarga, dukungan sosial, respons yang berlebihan terhadap kejadian hidup, serta pemikiran akan datangnya kematian (Hawari, 2013 dalam Sohat dkk., 2014).

Data epidemiologi menunjukkan bahwa gangguan kecemasan berkontribusi terhadap komorbiditas medis, dengan konsekuensi klinis yang tidak semestinya dan gangguan fungsional terjadi lebih mudah pada pasien yang sakit medis yang juga memiliki gangguan kecemasan (Lindesay, 1991 dalam Folks \& Fuller, 1997). Penelitian lain yang dilakukan menunjukkan bahwa ada hubungan tingkat kecemasan dengan kejadian insomnia pada lanjut usia di Posyandu Lansia Flamboyan Dusun Jetis Tamantirto Kasihan Bantul Yogyakarta tahun 2014 dengan kategori keeratan hubungan antara kedua variabel adalah sedang (Dhin, 2015).

Selain gangguan mental yang erat hubungannya dengan gangguan tidur, faktor-faktor psikososial seperti pensiun, isolasi, kesepian, dan berkabung juga berperan dalam kejadian insomnia pada lansia (Suzuki dkk., 2017). Penelitian lain mengenai kesepian pada lansia di Posyandu Lansia Tegar Kemlaten VII Surabaya juga menunjukkan hasil bahwa sebagian besar lansia yakni $78 \%$ dari 40 responden 
mengalami kesepian (Agus dkk., 2015). Kesepian merupakan suatu perasaan ketidaknyamanan subjektif individu karena tidak adanya hubungan erat dengan orang lain (Russell dkk., 1980). Aspekaspek kesepian diantaranya meliputi aspek kepribadian (personality), tidak adanya hubungan sosial yang diinginkan pada kehidupan di lingkungannya (social desirability), dan terganggunya perasaan individu (depression).

Berdasarkan hasil wawancara pada beberapa lansia di Surabaya, mereka juga merasakan kesepian walaupun mereka tinggal bersama dengan keluarganya di rumah. Hal ini dikarenakan anak-anak mereka sudah beranjak dewasa sehingga sibuk bekerja, dan ada pula yang sudah berkeluarga. Kesepian muncul di kalangan lansia yang tinggal di rumah karena pola keluarga yang mengarah pada pola keluarga inti (nuclear family) dimana anak-anak begitu sibuk dengan urusannya sendiri sehingga secara tidak langsung anak-anak kurang memperhatikan dan menjalin komunikasi yang intim dengan lansia. Lansia juga sering tidak dilibatkan dalam pengambilan keputusan di keluarganya. Hal tersebut membuat lansia merasa tersisih dan memicu timbulnya kesepian meskipun masih berada di lingkungan keluarga. Perasaan kesepian tersebut juga bertambah ketika fisik menurun dan aktivitas lansia menjadi berkurang (Cahyandari, 2017).

Menurut Launaigh \& Lawlor (2008 dalam Hacihasanoĝlu dkk., 2012) kesepian dapat menurunkan kualitas tidur, menyebabkan insomnia sepanjang hari, memiliki efek negatif pada kesehatan fisik dan mental, serta peningkatan penyakit jantung pada individu dengan kesepian. Kesepian telah terbukti memiliki hubungan dengan masalah tidur nokturnal dan kantuk di siang hari, terutama pada orang dewasa yang lebih tua (Aanes dkk., 2011). Sejalan dengan hal tersebut, penelitian yang dilakukan oleh Fitriana \& Purwanta (2013) menunjukkan hasil bahwa tingkat kesepian memiliki hubungan yang signifikan dengan tingkat insomnia pada lansia di Desa Srimulyo Kecamatan Piyungan Kabupaten Bantul Yogyakarta.

Kecemasan dan kesepian merupakan masalah yang dialami lansia dan memiliki keterkaitan dengan gangguan lainnya seperti insomnia. Namun masalah terkait gangguan pola tidur ini kurang mendapat perhatian dari lansia karena mereka menganggap gangguan tidur tersebut merupakan hal yang wajar sehingga mereka tidak memeriksakan gejalanya lebih lanjut. Hal tersebut membuat permasalahan ini seringkali tidak mendapat penanganan yang sesuai, sementara gangguan tidur dapat berdampak pada kualitas hidup orang yang berusia lanjut (Djauzi, 2010 dalam Dhin, 2015). Oleh karena itu penting untuk mengidentifikasi variabel lain yang berkaitan dengan kejadian insomnia seperti kecemasan dan kesepian. Keberhasilan penelitian ini nantinya dapat digunakan secara teoritis maupun praktis terkait masalah kecemasan, kesepian dan insomnia pada lansia. Berdasarkan kajian literatur yang sudah dipaparkan sebelumnya, hipotesis penelitian ini adalah kecemasan dan kesepian memiliki hubungan dengan insomnia pada lansia di Surabaya. Adapun tujuan dari penelitian ini adalah untuk mengetahui apakah ada hubungan antara kecemasan dan kesepian dengan insomnia pada lansia di Surabaya.

\section{Desain Penelitian}

\section{MET ODE}

Penelitian ini merupakan tipe penelitian kuantitatif yang umumnya menggunakan teknik pengambilan sampel secara acak, menggunakan instrumen penelitian, dan analisis datanya menggunakan metode statistik. Pemilihan tipe penelitian kuantitatif ini didasarkan pada tujuan penelitian yakni untuk menguji hipotesis dengan cara memperoleh nilai signifikansi hubungan antar variabel. Desain penelitian kuantitatif ini menggunakan metode survei untuk mengkaji populasi yang besar. Penentuan desain 
penelitian ini dikarenakan metode survei dapat mengkaji populasi yang besar dengan menggunakan sampel populasi untuk dapat membuat generalisasi terkait karakteristik pada populasi tersebut.

\section{Partisipan}

Partisipan dalam penelitian ini merupakan lansia yang tersebar di seluruh wilayah Surabaya $(N=94$, 59.6 persen perempuan). Penentuan jumlah sampel minimal $(N \geq 82)$ menggunakan bantuan software $G$ Power $(1-\beta=0.8, \alpha=0.05, \rho=0.3)$. Penentuan partisipan penelitian ini menggunakan teknik sampling purposive dimana pemilihan sampelnya didasarkan pada karakteristik tertentu sesuai tujuan penelitian. Adapun kriteria partisipan dalam penelitian ini terdiri dari: a.) lansia di Surabaya yang tinggal di rumah; b.) usia 60 tahun ke atas; dan c.) mengalami insomnia atau keluhan sulit tidur. Adapun proses pengumpulan data dilakukan baik secara offline maupun online melalui google form yang sudah disesuaikan dengan keterbatasan lansia dalam menggunakan teknologi sehingga proses pengisiannya dibantu oleh orang terdekat lansia.

\section{Pengukuran}

Insomnia didefinisikan sebagai kesulitan memulai dan/atau mempertahankan tidur secara terusmenerus (Savard dkk., 2003). Instrumen yang digunakan untuk mengukur insomnia adalah skala Insomnia Severity Index (ISI) yang dikembangkan oleh Morin dkk pada tahun 2011 (Morin dkk., 2011). Skala ini terdiri dari 7 aitem yang disusun berdasarkan dimensi tingkat keparahan gangguan tidur (severity), frekuensi kesulitan tidur (frequency), durasi kesulitan tidur (duration), dan konsekuensi siang hari (association daytime consequences). Skala ini dinilai mulai dari 0 hingga 4 poin sehingga total skor ISI diperoleh dengan menjumlahkan skor pada 7 aitem dengan kisaran 0 hingga 28. Skala Insomnia Severity Index telah diterjemahkan ke dalam Bahasa Indonesia oleh tim akademisi Mapi Research Trust dan dilakukan uji validitas dengan menghitung rata-rata skor individual content validity (i-CVI) yang didapat dari total i-CVI dibagi dengan kelima rater expert judgement pada masing-masing aitem. Skala insomnia pada penelitian ini memiliki rata-rata skor i-CVI $\geq 0,8$ dan nilai reliabilitas dari uji coba terpakai $(N=94 ; \alpha=0,929)$ sehingga ketujuh aitem digunakan seluruhnya pada penelitian ini.

Kecemasan didefinisikan sebagai respon terhadap berbagai macam tekanan yang mengakibatkan perasaan takut dan terancam (Segal dkk., 2010). Instrumen yang digunakan untuk mengukur kecemasan adalah skala Geriatric Anxiety Scale (GAS) yang dikembangkan oleh Segal dkk pada tahun 2010 (Segal dkk., 2010) dan dilakukan translasi secara forward (dari Bahasa Inggris ke Bahasa Indonesia) oleh Adismara Putri Pradini, S.Psi dan secara backward (dari Bahasa Indonesia ke Bahasa Inggris) oleh Wanodya Ratri, S.Psi. Skala ini memiliki 25 aitem yang disusun berdasarkan dimensi somatic yang melibatkan respon fisiologis, dimensi cognitive yang melibatkan respon subjektif dalam pikiran individu, serta dimensi affective yang melibatkan perasaan individu. Setiap aitem dinilai pada skala 4 ( 0 =tidak sama sekali; 1 =sesekali; 2 =hampir setiap saat; dan $3=$ selalu setiap saat). Uji validitas pada skala ini menggunakan rata-rata skor i-CVI $\geq 0$,8 yang didapat dari skor i-CVI dibagi dengan kelima rater expert judgement pada masing-masing aitem. Hasil uji validitas menunjukkan bahwa semua aitem memiliki rata-rata i-CVI $\geq 0,8$ kecuali aitem nomor 5 sehingga penulis memperbaiki translasi aitem berdasarkan masukan dari expert judgement agar aitem tersebut menjadi valid dan dapat digunakan. Skala ini juga telah dilakukan uji reliabitas dengan menggunakan uji coba terpakai dan didapatkan nilai reliabilitas sebesar 0,905 . Nilai reliabilitas tersebut didapatkan setelah dilakukan pengguguran pada aitem nomor 23 karena tidak reliabel (skor korelasi aitem total $<0,25$ ) sehingga total aitem yang digunakan pada penelitian ini adalah 24 aitem. Total skor GAS diperoleh dengan menjumlahkan skor pada 24 aitem sehingga skor terendah yang didapat adalah 0 dan skor tertinggi 72. 
Kesepian didefinisikan sebagai suatu perasaan ketidaknyamanan subjektif individu karena tidak adanya hubungan erat dengan orang lain (Russell dkk., 1980). Instrumen yang digunakan untuk mengukur kesepian adalah skala UCLA Loneliness Scale version 3 yang dikembangkan oleh Russell pada tahun 1996 berdasarkan dimensi personality, social desirability serta depression dan skala ini sudah dilakukan studi pada berbagai populasi, termasuk lansia (Russell, 1996). Skala ini terdiri dari 20 aitem dimana 11 aitem merupakan aitem favorable (menggambarkan kesepian) dan 9 aitem lainnya merupakan aitem unfavorable (tidak menggambarkan kesepian). Setiap aitem dinilai pada skala 4 (1=tidak pernah; 2=jarang; 3 =sesekali; 4=selalu) dan nilai skala ini dikonversi terbalik pada aitem unfavorable (Russell, 1996). Semua aitem dinilai valid pada penilaian rater expert judgement dengan rata-rata skor i-CVI $\geq 0,8$ namun penelitian ini hanya menggunakan 19 aitem dikarenakan aitem nomor 8 dinilai tidak reliabel (skor korelasi item total < 0,25). Total skor UCLA Loneliness version 3 diperoleh dengan menjumlahkan skor pada 19 aitem sehingga skor terendah adalah 19 dan skor tertinggi 76.

\section{Analisis Data}

Teknik analisa data yang digunakan untuk menguji hipotesis penelitian ini adalah teknik korelasi dari Pearson's Product Moment karena data penelitian telah memenuhi uji asumsi (normalitas dan linearitas). Penulis juga melakukan analisis tambahan pada salah satu variabel penelitian (variabel insomnia) dengan menggunakan uji Independent Sample T-Test untuk perbandingan 2 kelompok dan One Way Anova (untuk perbandingan 3 kelompok) guna mengetahui perbedaan hasil insomnia jika ditinjau berdasarkan data sosiodemografis. Perangkat lunak yang digunakan untuk menganalisa data penelitian ini adalah SPSS 25 for Windows.

\section{HAS I L P EN ELIT IAN}

Hasil analisis deskriptif menunjukkan bahwa partisipan memiliki rata-rata skor insomnia yang berada pada kategori subthreshold $(\mathrm{N}=94 ; \mathrm{M}=10,49 ; \mathrm{SD}=6,507)$, rata-rata skor kecemasan berada pada kategori sedang $(\mathrm{N}=94 ; \mathrm{M}=19,68, \mathrm{SD}=11,246)$, dan rata-rata skor kesepian berada pada kategori sedang $(\mathrm{N}=94 ; \mathrm{M}=38,82 ; \mathrm{SD}=7,779)$.

Hasil analisis uji normalitas Kolmogrov-Smirnov menunjukkan bahwa ketiga variabel berdistribudi tidak normal $(p<0,05)$. Data variabel insomnia dan kecemasan berdistribusi normal setelah dilihat dari rasio kurtosis yang berada pada rentang -2 hingga 2 (rasio kurtosis insomnia = 1,86; rasio kurtosis kecemasan $=1,46)$. Rasio kurtosis didapat dari perhitungan nilai statistik kurtosis dibagi standar eror. Distribusi data pada variabel kesepian tetap tidak normal jika dilihat dari rasio kurtosis sehingga dilakukan transform data berdasarkan kemiringan distribusi data dengan rumus $\operatorname{SQRT}(x)(p=0,200)$ sehingga data menjadi normal. Hasil analisis uji linearitas menunjukkan bahwa nilai signifikansi antara variabel kecemasan dengan variabel insomnia $(p=0,113)$ dan variabel kesepian dengan variabel insomnia $(p=0,066)$ memiliki hubungan yang linear $(p>0,05)$.

Berdasarkan hasil analisis uji korelasi terdapat hubungan yang signifikan antara kecemasan dan insomnia $(r(94)=0,694 ; p=0,000)$, hubungan yang signifikan antara kesepian dan insomnia $(r(94)=0,346 ; p=0,001)$, dan secara bersama-sama variabel kecemasan dan kesepian memiliki hubungan yang signifikan dengan insomnia $(R(94)=0,987 ; p=0,000)$.

Hasil analisis tambahan menggunakan uji independent sample t-test terkait perbedaan insomnia berdasarkan gender $(F(1,94)=0,033 ; p=0,492>0,05)$ menunjukkan tidak terdapat perbedaan yang signifikan pada hasil insomnia antara sampel laki-laki dan perempuan. Hasil analisis perbedaan

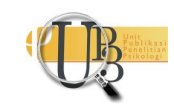


insomnia berdasarkan status pekerjaan $(F(1,94)=0,014 ; p=0,538>0,05)$ menunjukkan tidak terdapat perbedaan yang signifikan pada hasil insomnia antara sampel yang bekerja dan sampel yang tidak bekerja. Hasil analisis perbedaan insomnia berdasarkan status kegiatan $(F(1,94)=0,564 ; p=0.706>0,05)$ menunjukkan tidak terdapat perbedaan yang signifikan pada hasil insomnia antara sampel yang memiliki kegiatan dan sampel yang tidak memiliki kegiatan. Hasil analisis perbedaan insomnia berdasarkan status riwayat medis $(F(1,94)=0,72 ; p=0,137>0,05)$ menunjukkan tidak terdapat perbedaan yang signifikan pada hasil insomnia antara sampel yang memiliki riwayat medis dan sampel yang tidak memiliki riwayat medis.

Hasil analisis tambahan menggunakan One Way Anova untuk menguji perbedaan insomnia berdasarkan status perkawinan (dibagi dalam 3 kelompok), menunjukkan bahwa tidak terdapat perbedaan yang signifikan pada hasil insomnia antara sampel yang masih memiliki pasangan, sampel yang sudah janda/duda, dan sampel yang tidak menikah $(F(2,94)=0,12 ; p=0,988>0,05)$.

\section{I S K U S I}

Hasil analisis dalam penelitian ini menunjukkan bahwa terdapat hubungan yang signifikan antara kecemasan dan kesepian dengan insomnia pada lansia di Surabaya. Selain itu, kecemasan dan kesepian memiliki arah hubungan yang positif dengan insomnia dimana semakin tinggi kecemasan dan kesepian yang dialami maka semakin tinggi pula tingkat insomnianya. Hasil penelitian ini sejalan dengan temuan sebelumnya yang menunjukkan bahwa ada hubungan tingkat kecemasan dengan kejadian insomnia pada lanjut usia di Posyandu Lansia Flamboyan Dusun Jetis Tamantirto Kasihan Bantul Yogyakarta (Dhin, 2015). Penelitian lain juga menunjukkan bahwa tingkat kesepian memiliki hubungan yang signifikan dengan tingkat insomnia pada lansia di Desa Srimulyo Kecamatan Piyungan Kabupaten Bantul Yogyakarta (Fitriana \& Purwanta, 2013). Sejalan dengan literatur tersebut, kesepian juga terbukti memiliki hubungan dengan masalah tidur nokturnal dan kantuk di siang hari, terutama pada orang dewasa yang lebih tua (Crewdson, 2016). Hal ini dikarenakan kecemasan dan kesepian yang dialami mengakibatkan perubahan pada ritme sirkadian dalam tidur sehingga menimbulkan masalah tidur seperti insomnia (Dermay dkk, 1996 dalam Folks \& Fuller, 1997).

Hasil analisis tambahan yang dilakukan pada penelitian ini juga menunjukkan bahwa tidak ada perbedaan pada skor insomnia jika ditinjau dari berbagai data sosiodemografis responden. Hal ini menunjukkan bahwa insomnia dapat terjadi pada lansia laki-laki maupun perempuan, lansia yang memiliki pasangan ataupun tidak memiliki pasangan, lansia yang masih bekerja atau sudah tidak bekerja, lansia yang memiliki kegiatan ataupun tidak memiliki kegiatan, serta lansia yang memiliki riwayat medis ataupun tidak memiliki riwayat medis. Sejalan dengan temuan tersebut, insomnia dapat terjadi karena lansia memang mengalami proses penuaan secara alami baik pada laki-laki maupun perempuan. Menurut Potter dkk (2009 dalam Putri, 2019) proses penuaan yang terjadi pada lansia meliputi perubahan fisiologis, kognitif, dan psikososial. Proses penuaan juga menyebabkan munculnya permasalahan kesehatan dan perubahan status pekerjaan pada lansia sehingga lansia mengalami kecemasan serta perasaan kesepian yang juga dapat muncul ketika kondisi fisik dan aktivitas sosial menurun (Cahyandari, 2017).

Lansia dalam penelitian ini juga mengalami penurunan fisik dan permasalahan kesehatan seperti diabetes, darah tinggi, pengapuran tulang dan penyakit medis lainnya. Adanya perasaan cemas terhadap masalah kesehatan fisik yang juga muncul di malam hari membuat lansia mengalami kesulitan untuk tidur. Hal ini sejalan dengan teori perkembangan yang menjelaskan bahwa lansia harus menghadapi tugas perkembangan yang terkait dengan kemampuan menerima fungsi tubuh yang menurun. Pada

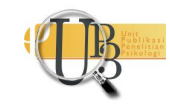


tugas perkembangan ini, lansia yang mampu menyadari dan menerima bahwa penurunan fisik yang terjadi adalah bagian dari penuaan, maka mereka akan berfokus pada aktivitas yang masih bisa dilakukan dan mampu menjalin hubungan sosial. Namun, bagi lansia yang hanya berfokus pada penyakit tubuh dan memikirkannya secara terus menerus maka mereka akan menjadi lebih lemah serta dapat mengalami kecemasan (Peck, 1956).

Namun lansia yang tidak mengalami masalah kesehatan pun tidak menutup kemungkinan untuk dapat mengalami kecemasan. Lansia juga sering mengeluhkan bahwa mereka mudah merasa lelah saat beraktivitas. Mereka juga mudah marah dan tersinggung, serta kurang fokus. Sementara itu, mereka tidak memiliki riwayat penyakit medis lainnya. Hal ini berkaitan dengan salah satu kriteria diagnosis menurut DSM IV bahwa kecemasan dikaitkan dengan beberapa gejala seperti gelisah, tegang, mudah lelah, sulit konsentrasi, dan mudah marah (APA, 1994). Gejala seperti mudah lelah dan sebagainya dapat muncul karena memang hal tersebut adalah bagian dari proses penuaan. Menurut Juniarti (2008 dalam Fitriana \& Purwanta, 2013) lansia yang tidak siap dengan proses penuaan yang terjadi akan rentan mengalami masalah psikologis seperti kecemasan yang kemudian mengarah pada insomnia.

Selain menurunnya kapasitas fungsional yang dialami oleh lansia, mereka juga harus menghadapi bahwa dirinya menjadi lebih pasif dalam pekerjaan dibanding sebelumnya karena kemampuan fisiknya yang kurang memadai untuk menjalani pekerjaan. Beberapa lansia di Surabaya umumnya juga sudah tidak lagi bekerja. Adapun lansia yang masih bekerja juga harus menyesuaikan jenis pekerjaan dan intensitasnya dengan kemampuan fisik mereka. Oleh karena itu, pekerjaan yang mereka lakukan tidak seberat saat mereka masih berusia muda. Perubahan dalam pekerjaan dapat menimbulkan kecemasan dan kemudian mengakibatkan gangguan tidur (Oh dkk., 2019).

Penurunan kapasitas fungsional juga membuat lansia dihadapkan pada peningkatan ketergantungan terhadap orang lain dan kebutuhan terkait perawatan kesehatan. Lansia yang tidak memiliki penghasilan sendiri dinilai gagal dalam pemenuhan kebutuhan ekonomi sehingga dapat memberikan tekanan kehidupan yang membuat mereka mengalami kecemasan. Hal ini sejalan dengan penelitian lain bahwa lansia dipandang sebagai individu yang identik dengan pikun, jompo, ringkih, sakit-sakitan, dan menghabiskan uang untuk berobat (Yuliati dkk., 2014). Perubahan status keuangan juga menimbulkan kecemasan yang kemudian mengarah pada gangguan tidur (Oh dkk., 2019).

Lansia tidak hanya mengalami perubahan aktivitas fisik, melainkan mereka juga mengalami perubahan sosial seperti partisipasinya dalam mengikuti kegiatan sosial. Beberapa lansia di Surabaya masih tetap aktif mengikuti kegiatan sosial meski hanya cenderung mengikuti kegiatan yang melibatkan orangorang seusianya saja. Misalnya seperti pengajian, perkumpulan lansia, senam lansia dan sebagainya. Lansia lebih dapat berkumpul bersama orang seusianya, karena mereka dapat saling menyemangati dan berbagi mengenai masalahnya (Yuliati dkk., 2014).

Namun beberapa lansia lainnya memilih untuk tidak mengikuti kegiatan. Mereka lebih pasif dalam hubungan sosial karena keterbatasan fisik dan masalah kesehatan yang mereka alami seperti lumpuh atau gangguan penglihatan. Lansia juga merasa bahwa diri mereka tidak lagi berdaya untuk melakukan aktivitas sehari-hari sehingga mereka cenderung menarik diri dari partisipasi sosial. Hal ini juga sejalan dengan penelitian lain bahwa lansia mengalami penurunan kemampuan fisik yang mengakibatkan menurunnya interaksi sosial dan cenderung menghindari hubungan dengan orang lain, sehingga berkurangnya interaksi sosial mengakibatkan mereka mengalami kesepian (Samper, 2016). Selain itu, menurut Jylha (2004 dalam Hacihasanoĝlu dkk., 2012) kurangnya kepercayaan pada orang lain, takut menjadi sasaran agresi dan berkurangnya dukungan keuangan membuatnya mengisolasi diri dari masyarakat sehingga semakin menambah perasaan kesepian dan keterasingannya. Aktivasi psikologis (kognisi) pada individu yang mengalami kesepian cenderung berpusat pada ketidakcukupan hubungan 
sosial. Perasaan isolasi emosional yang masih muncul pada waktu tidur, memiliki peranan dalam pengembangan dan pemeliharaan kesulitan tidur (Harvey dkk., 2005).

Selain berkurangnya interaksi sosial, lansia juga harus menghadapi bahwa pasangan mereka sudah tidak ada atau tidak seperti apa yang diharapkannya. Terlebih lagi anak-anak mereka juga sudah berkeluarga dan tidak memiliki waktu sepenuhnya untuk merawat mereka. Keadaan inilah yang menurut Marini \& Hayati (2012 dalam Ardianto, 2015) dapat menimbulkan keadaan mental dan emosional seperti perasaan terasing serta kurangnya hubungan yang bermakna dengan orang lain. Hal ini membuat lansia mengalami kesepian. Kesepian yang dialami oleh lansia menyebabkan mereka menjadi rendah diri, tidak ingin berusaha untuk terlibat pada kegiatan sosial, takut bertemu orang lain dan menghindari situasi baru. Kondisi psikologis ini terus terbawa dalam alam pikiran lansia, sehingga akan menimbulkan kesulitan untuk tidur, mudah terbangun ketika sedang tidur, dan pada akhirnya akan menimbulkan insomnia pada lansia (Ardianto, 2015).

Penurunan kemampuan fisiologis dan perubahan sosial yang telah dijelaskan sebelumnya dapat menyebabkan lansia mengalami kecemasan dan kesepian. Hal ini sejalan dengan penelitian yang dilakukan oleh Hawari (2013 dalam Sohat dkk., 2014) bahwa penyakit medis fisiologi yang sulit diatasi, kehilangan pasangan hidup, pekerjaan, keluarga, dukungan sosial dan respons yang berlebihan terhadap kejadian hidup menyebabkan lansia mengalami kecemasan yang kemudian mengarah pada kejadian insomnia. Selain itu, perubahan sosial seperti pensiun, isolasi, kesepian dan berkabung juga berperan dalam kejadian insomnia pada lansia (Suzuki dkk., 2017).

\section{S I M P U L A N}

Berdasarkan hasil penelitian ini dapat disimpulkan bahwa ada hubungan yang signifikan antara masingmasing variabel kecemasan dan kesepian dengan insomnia pada lansia di Surabaya. Selain itu, kecemasan dan kesepian secara bersama-sama juga memiliki hubungan yang signifikan dengan insomnia. Arah hubungan antara kecemasan dan kesepian dengan insomnia menunjukkan arah yang positif. Hal ini menunjukkan bahwa semakin tinggi kecemasan dan kesepian yang dialami oleh lansia, maka semakin tinggi pula tingkat insomnia nya. Penelitian ini juga menyimpulkan bahwa insomnia dapat terjadi pada lansia terlepas dari berbagai indikator sosiodemografi, jaringan sosial, dan status kesehatan.

Penulis menyadari bahwa penelitian ini tentunya memiliki keterbatasan. Oleh karena itu penulis mengajukan beberapa saran diantaranya untuk penelitian berikutnya dapat menentukan variabel lainnya yang diprediksi dapat menjadi anteseden insomnia sehingga dapat memperkaya kajian mengenai insomnia pada lansia bahkan di lingkup yang lebih luas, tidak hanya di Surabaya. Penelitian berikutnya juga dapat melakukan analisis yang tidak dilakukan pada penelitian ini, seperti analisis terkait dimensi kecemasan dan kesepian dengan setiap tingkatan insomnia, atau analisis terkait perbedaan tingkatan kecemasan dan kesepian berdasarkan data sosiodemografi yang ada. Selain itu penulis juga menyarankan agar lansia yang mengalami kesulitan tidur dapat mengevaluasi penyebabnya, menerapkan jadwal tidur-bangun yang sama di setiap harinya, dan melakukan aktivitas fisik secara ringan untuk menjaga kesehatan fisiknya. Penulis juga mengajukan saran kepada pihak keluarga lansia serta kader-kader posyandu lansia untuk dapat melibatkan lansia dalam kegiatan sehari-hari maupun kegiatan sosial, memeriksa kesehatan lansia secara rutin, merancang program yang mampu mengatasi atau mengurangi masalah insomnia, kecemasan, dan kesepian pada lansia seperti kegiatan pengajian, senam lansia, penerapan teknik relaksasi, meditasi, yoga, dan semacamnya. 


\section{U CAPAN TERIMAKASIH}

Penulis mengucapkan terima kasih kepada Tuhan Yang Maha Esa atas segala nikmat dan rahmat yang telah dilimpahkan kepada penulis, kepada dosen pembimbing penulis Dr. Hamidah, M.Si., Psikolog, kepada orang tua penulis, serta kepada lansia di Surabaya yang sudah bersedia menjadi partisipan dalam penelitian ini.

\section{DEKLARASI POTENSI TERJADINYA KONFLIK KEPENTINGAN}

Desi Puspita Sari dan Hamidah tidak bekerja, menjadi konsultan, memiliki saham, atau menerima dana dari perusahaan atau organisasi manapun yang mungkin akan mengambil untung dari diterbitkannya naskah ini.

\section{P UST AKA ACUAN}

Aanes, M. M., Hetland, J., Pallesen, S., \& Mittelmark, M. B. (2011). Does loneliness mediate the stresssleep quality relation? the Hordaland Health Study. International Psychogeriatrics, 23(6), 9941002. https://doi.org/10.1017/S1041610211000111

Agus, A., Halawa, A., \& Booth, A. W. (2015). Dukungan Sosial Keluarga dengan Kesepian pada Lansia Di Posyandu Lansia Tegar Kemlaten VII Surabaya.

Ancoli-Israel, S., \& Cooke, J. R. (2005). Prevalence and comorbidity of insomnia and effect on functioning in elderly populations. Journal of the American Geriatrics Society, 53(7 SUPPL.), 264-271. https://doi.org/10.1111/j.1532-5415.2005.53392.x

APA. (1994). Diagnostic and Statistical Manual of Mental Disorders Fourth Edition. https://doi.org/10.1016/j.psychres.2011.06.006

Ardianto, H. D. (2015). Hubungan tingkat kesepian dengan kejadian insomnia pada lansia di pstw yogya unit budiluhur kasongan bantul. 1-10. http://digilib.unisayogya.ac.id/73/1/NASKAH PUBLIKASI.pdf

BPS. (2020). Proyeksi Penduduk Kota Surabaya Menurut Jenis Kelamin dan Kelompok Umur. diakses pada $\begin{array}{llll}\text { tanggal } & 11 & \text { Maret } & 2020 \\ \end{array}$ https://surabayakota.bps.go.id/dynamictable/2018/04/18/24/proyeksi-penduduk-kotasurabaya-menurut-jenis-kelamin-dan-kelompok-umur-tahun-2020.html.

Buysse, D., \& Merrigan, J. (2013). Insomia. The Journal of the American Medical Association, 309(7), 2013.

Cahyandari, R. (2017). Kesepian pada Lansia. Puskesmas Dlingo II - Bantul [on-line]. Diakses pada tanggal 20 Maret 2021 dari https://puskesmas.bantulkab.go.id/dlingo2/2017/09/22/kesepian-pada-usialanjut-lansia-usila/.

Crewdson, J. A. (2016). The Effect of Loneliness in the Elderly Population: A Review. Healthy Aging \& Clinical Care in the Elderly, 8, 1-8. https://doi.org/10.4137/hacce.s35890

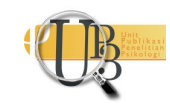


Crowley, K. (2011). Sleep and sleep disorders in older adults. Neuropsychology Review, 21(1), 41-53. https://doi.org/10.1007/s11065-010-9154-6

Dhin, A. F. (2015). Kejadian Insomnia Pada Lanjut Usia. Jurnal Keperawatan Indonesia. https://repository.unej.ac.id/bitstream/handle/123456789/3193/ Ericha Aditya Raharja 062310101038.pdf?sequence=1

Fitriana, V., \& Purwanta, S. K. (2013). Hubungan antara Tingkat Kesepian dengan Tingkat Insomnia pada Lanjut Usia di Desa Srimulyo Kecamatan Piyungan Bantul Yogyakarta.

Folks, D. G., \& Fuller, W. C. (1997). Anxiety disorders and insomnia in geriatric patients. Psychiatric Clinics of North America, 20(1), 137-164. https://doi.org/10.1016/S0193-953X(05)70398-1

Hacihasanoĝlu, R., Yildirim, A., \& Karakurt, P. (2012). Loneliness in elderly individuals, level of dependence in activities of daily living (ADL) and influential factors. Archives of Gerontology and Geriatrics, 54(1), 61-66. https://doi.org/10.1016/j.archger.2011.03.011

Harvey, A. G., Schmidt, D. A., Scarnà, A., Semler, C. N., \& Goodwin, G. M. (2005). Sleep-related functioning in euthymic patients with bipolar disorder, patients with insomnia, and subjects without sleep problems. American Journal of Psychiatry, 162(1), 50-57. https://doi.org/10.1176/appi.ajp.162.1.50

Jannati, R. A. (2019). Efektivitas Terapi Tawa Yoga terhadap Kesejahteraan Subjektif Lansia yang Mengalami Depresi.

Kholifah, S. N. (2016). Keperawatan Gerontik.

Morin, C., \& Benca, R. (2012). Chronic insomnia. The Lancet, 379, 1488. https://doi.org/10.1016/S01406736(12)60632-1

Morin, C. M., Belleville, G., Bélanger, L., \& Ivers, H. (2011). The insomnia severity index: Psychometric indicators to detect insomnia cases and evaluate treatment response. Sleep, 34(5), 601-608. https://doi.org/10.1093/sleep/34.5.601

Oh, C. M., Kim, H. Y., Na, H. K., Cho, K. H., \& Chu, M. K. (2019). The effect of anxiety and depression on sleep quality of individuals with high risk for insomnia: A population-based study. Frontiers in Neurology, 10(JUL), 1-8. https://doi.org/10.3389/fneur.2019.00849

Patel, D., Steinberg, J., \& Patel, P. (2018). Insomnia in the elderly: A review. Journal of Clinical Sleep Medicine, 14(6), 1017-1024. https://doi.org/10.5664/jcsm.7172

Peck, R. (1956). Psychological developments in the second half of life. In Conference on Planning Research.

Putri, D. A. (2019). Status Psikosoial Lansia di PSTW Abiyoso Pakem Sleman Yogyakarta tahun 2019.

Rajput, V., \& Bromley, S. M. (1999). Chronic insomnia: A practical review. American Family Physician, 60(5), 1431-1442. 
Russell, D. (1996). UCLA Loneliness Scale (Version 3): Reliability, validity, and factor Structure. Journal of Personality Assessment, 66(1), 20-40. https://doi.org/10.1207/s15327752jpa6601

Russell, D., Peplau, L., \& Cutrona, C. (1980). The revised UCLA Loneliness Scale: concurrent and discriminant validity evidence. Journal of personality and social psychology, 39(3), 472-480.

Samper, T. P. (2016). Hubungan Interaksi Sosial dengan Kualitas Hidup di PBLU Senja Cerah Provinsi Sulawesi Utara. Jurnal EMBA, 4(1), 484-495.

Savard, J., Laroche, L., Simard, S., Ivers, H., \& Morin, C. M. (2003). Chronic insomnia and immune functioning. Psychosomatic Medicine, 211-221. https://doi.org/10.1097/01.PSY.0000033126.22740.F3

Segal, D. L., June, A., Payne, M., Coolidge, F. L., \& Yochim, B. (2010). Development and initial validation of a self-report assessment tool for anxiety among older adults: The Geriatric Anxiety Scale. Journal of Anxiety Disorders, 24(7), 709-714. https://doi.org/10.1016/j.janxdis.2010.05.002

Sohat, F., Bidjuni, H., \& Kallo, V. (2014). Hubungan Tingkat Kecemasan Dengan Insomnia Pada Lansia Di Balai Penyantunan Lanjut Usia Senja Cerah Paniki Kecamatan Mapanget Manado. Jurnal Keperawatan UNSRAT, 2(2), 113320.

Sumirta, I. N., \& Laraswati, A. I. (2014). Faktor Yang Menyebabkan Gangguan Tidur (Insomnia) Pada Lansia. Politeknik Kesehatan Denpasar, 1-10.

Suzuki, K., Miyamoto, M., \& Hirata, K. (2017). Sleep disorders in the elderly: Diagnosis and management. Journal of General and Family Medicine, 18(2), 61-71. https://doi.org/10.1002/jgf2.27

Vibriyanti, D. (2018). Surabaya menuju kota ramah lansia: peluang dan tantangan. Jurnal Kependudukan Indonesia, 13(2), 117-132.

Yola, P. (2016). Hubungan tingkat kecemasan dengan derajat insomnia pada lanjut usia di Posyandu Lanjut Usia Mekar Sari Mojo Surabaya Tahun 2016.

Yuliati, A., Baroya, N., \& Ririanty, M. (2014). Perbedaan kualitas hidup lansia yang tinggal di komunitas dengan di pelayanan sosial lanjut usia. Jurnal Pustaka Kesehatan, 2(1), 87-94. 